\title{
The Efficiency of Halal Processed Food Industry in Malaysia
}

\author{
Mohd Ali Mohd Noor (Corresponding author) \\ Faculty of Economics and Management, Universiti Kebangsaan Malaysia, \\ 43600 Bangi, Selangor, Malaysia \\ Tel: +603-89215606 E-mail: ali@ukm.edu.my \\ Mohammed Rizki Moi \\ Faculty of Economics and Management, Universiti Kebangsaan Malaysia, \\ 43600 Bangi, Selangor, Malaysia \\ $\&$
}

Faculty of Management and Muamalah, International Islamic University College Selangor, KUIS, Bandar Seri Putra, 43000 Kajang, Selangor, Malaysia

Tel: +603-89215733 E-mail: rizkiukm@gmail.com

Radiah Abdul Kader

Faculty of Economics and Administration, University of Malaya, 50603

Kuala Lumpur, Malaysia

Tel: +603-79673654 E-mail: radiah@um.edu.my

\begin{abstract}
Efficiency is indispensable for an industry to ensure cost reduction and profit maximization. It also helps the industry to be competitive and remain in the market. In 2010, Malaysia aims to be the world halal hub. The hub should capture at least five percent of the world halal market with at least 10,000 exporting firms. However the hub failed due to the small number of firms efficiency that finally contribute to less number of firms export. Thus, this study aimed to measure the efficiency of halal processed food industry in Malaysia using Data Envelopment Analysis (DEA). Input variables used were local raw inputs, labour, and monetary assets of halal food industry in Malaysia. Meanwhile the output used was the total sales revenue of the halal industry in Malaysia. The study shows that very few indusries are efficient in each category led by meat, dairy, cordials and juices, marine products, food crops, and grains industry. Therefore, the government needs to emphasize on industry's efficiency to be competitive and be the world halal hub in the future.
\end{abstract}

Keywords: DEA, Efficiency; Halal food industry, Processed food

\section{Introduction}

In general, halal food industry refers to the sector involved in the processing of food and beverage products that comply with Islamic law in terms of inputs, manufacturing process, packaging, and marketing. In Malaysia, there are several main processed food industries namely industrial production of grain-based foods, dairy products, food crops products, marine products, meat products, and cordial beverages. Halal processed food industry has a huge market and able to strengthen its relationship with the agricultural sector through its own niche market (Idris et al., 2007). Although halal processed food industry existed in Malaysia a very long time ago, entrepreneurs started to show great interests towards this industry when it began to show a high commercial value and broad market coverage lately (Sungkar, 2004).

According to the Second Industrial Master Plan (IMP II), Malaysia intended to be the world halal hub by the year 2010. In order to be competitive, the hub should consists at least 10,000 exporting firms. This number of firms will expected to capture at least five percent of the world halal market. Report by Malaysian 
Halal Development Corporation (HDC, 2010) confirmed that in 2010, there is approximately 7,000 halal firms in Malaysia and majority of them are not exporting oriented. The inability to export is expected as a result of few number of firms efficiency.

Ismail and Radam (2004) reported that the efficiency of the country's food processing industry is relatively low. Raziah (2003) who studied the efficiency of fish-based foodprocessing firms also found that the efficiency of the firms declined in 1998 compared to the results produced in 1996. Noor and Ismail (2007) have reviewed the efficiency of small and medium industries in Malaysia and found that most firms in small and medium scale industries are relatively inefficient.

Although many studies regarding the efficiency of food industry in Malaysia have been carried out, there is no study focusing on the halal food industry individually. Therefore, the aim of this study is to measure the efficiency of halal food industry in Malaysia that consists of meat, dairy, cordial and juice, marine products, food crops, and grains industry.

Farrell (1957) has introduced the concept of economic efficiency which has been used by many researchers to measure the efficiency and performance of the firm. Farrell (1957: 254) has defined efficiency as "the success in producing output as large as possible from a given set of input", while the efficient production function is "the output that is perfectly efficient obtained from any given combination of inputs". Becoming an efficient firm is important in order to reduce the costs. Once the efficiency value is acquired, the average relative efficiency values of all firms within the same industry could be measured to determine the efficiency of various other industries.

A study conducted by Nickell (1996) indicated that market concentration has an inverse correlation with technical efficiency. It means that the boost in market concentration or market share will reduce the technical efficiency when above a certain threshold (Nickell, 1996). In addition, firms that are effective in marketing, efficient in production operations and managing human resources could be considered as competitive firms. A study conducted by Brown and Earle (2000) found that the competitions among firms for local products, imported products, and local labour resources showed a positive correlation between competitiveness and efficiency of the firms.

To determine the value of relative efficiency of each firm, non-parametric analysis of Data Envelopment Analysis (DEA) are used on grains, dairy products, marine products, meat products, and others. It was introduced by Charnes et al. 1978 and this study has become the foundation of developing the non-parametric efficiency measurement. According to Charnes and Cooper (1984), 100 percent efficiency is defined as:

i) no output(s) could be increased without increasing the value of one or more inputs; or must reduce other outputs; or ii) no input(s) could be reduced without decreasing the value of output; or increasing other inputs.

As explained by Cooper and Lovell (2000), DEA is made based on linear-based programming technique to measure efficiency in which several inputs and outputs are required. Furthermore, DEA is capable of recognising inefficient units and provides the solutions to remedy the situations. DEA application is usually used by public sectors, nevertheless private sectors have started to adopt the same application.

The first advantage of DEA is its non-parametric characteristic. Therefore, it is not bounded by strict assumptions that may imply the weaknesses of a method in measuring efficiency. This method uses mathematical formulae to compute efficiency and propose improvements based on raw data. DEA concept is easy to understand and there are many software that use DEA are available in the market. Secondly, 
DEA is superior in measuring the efficiency of an individual against other individual(s) in the same group by providing detailed information about the efficiency of individual manufacturing processes (Webster et al., 1998). Thirdly, DEA has its own advantages over other methods of measurement; such as its approach in profit calculation, ratio analysis, econometrics, and Stochastic Frontier Analysis (SFA). Due to that, there are many fields of study are applied DEA in their research (Tavares, 2003).

\section{Methodology}

This study used primary data obtained from the questionnaires that were collected from 295 halal firms in Malaysia and were analysed by DEA to measure the efficiency of Malaysia's halal food industry. To determine the efficiency of various industries, the relative efficiency of all firms in the same industry should be measured in advance. Then all of the firm's efficiency was averaged to produce an average efficiency of the industry. After that, the percentage of the competent firm in a particular industry could be determined. The average efficiency of all firms in a given industry will indicate the overall efficiency of the industry.

When there are multiple inputs and outputs, efficiency can be defined as:

$$
\text { Efficiency }=\frac{\text { weighted sum of output }}{\text { weighted sum of input }}
$$

However, the equation mentioned above gives a problem in terms of finding the weight. Charnes et al. (1978) suggested that the maximum efficiency of Decision Making Unit (DMU) $\mathrm{k}_{\mathrm{o}}$ is calculated by solving the problem below:

$$
\operatorname{Max} h_{o}=\frac{\sum_{j=1}^{n} W_{j} Y_{j k o}}{\sum_{i=1}^{m} V_{i} X_{i k o}}
$$

subject to,

$$
\frac{\sum_{j=1}^{n} W_{j} Y_{j k o}}{\sum_{i=1}^{m} V_{i} X_{i k o}} \leq \quad(k=1, \ldots . . z)
$$

wj, vi $\geq \varepsilon$ for all i.j

where :

$\mathrm{z}=$ number of unit;

$\mathrm{m}=$ number of input;

$\mathrm{n}=$ number of output;

$\mathrm{v}_{\mathrm{i}}=$ weighted sum of input $\mathrm{i}$;

$\mathrm{w}_{\mathrm{j}}=$ weighted of output $\mathrm{j}$;

$\mathrm{Y}_{\mathrm{j} \mathrm{k}}=$ sum of output $\mathrm{j}$ obtained by DMUj;

$\mathrm{X}_{\mathrm{ik}}=$ sum of output $\mathrm{i}$ obtained by DMUj;

$\varepsilon=$ small positive value.

Since the DEA model mentioned above is a fractional linear programming problem, it must be converted to a linear form so that linear programming methods can be used to solve them.

The linear form of the problem is as follows" to maximize

$$
\mathrm{h}_{0}=\sum_{\mathrm{j}=1}^{\mathrm{n}} \mathrm{W}_{\mathrm{j}} \mathrm{Y}_{\mathrm{jko}}
$$

Subject to,

$$
\sum_{n=1}^{m} V_{i} X_{i k o}
$$

$$
\sum_{\mathrm{j}=1}^{\mathrm{n}} \mathrm{W}_{\mathrm{j}} \mathrm{Y}_{\mathrm{jko}}-\sum_{\mathrm{i}=1}^{\mathrm{m}} \mathrm{V}_{\mathrm{i}} \mathrm{X}_{\mathrm{iko}} \leq 1 \quad(\mathrm{k}=1, \ldots . \mathrm{z})
$$

$w j, v i \geq \varepsilon$

for all $\mathrm{i}, \mathrm{j}$

Maximization is performed two times in order to produce a maximum efficiency of h0, an output maximum weight of wj, and an input maximum weight of $v j$ for each DMU ko. This model will maximize the weighted ratio of output to input for ko of DMU. The ratio restraint for other DMU unit will not exceed the unity (in which unity is the efficiency maximum). The value of DMU efficiency will either be 1.0 (efficient) or less than 1.0 
(inefficient). In this case, the output-oriented model is employed with constant returns to scale. Output-oriented means that the input efficiency can be improved so that the output will be increased. In addition, the constant returns to scale means that similar changes in the input will cause the rise of output at the same rate. Another aspect of DEA technique that is interesting is the weight of input and output could be determined by the model itself (Cook \& Zhu, 2006; Norman \& Stooker, 1991). The DEA model would choose positive values of weight in order to maximize the efficiency of the firm relative to the constraint of each firm, using
Table 1: Types of industry and number of firms

\begin{tabular}{|c|c|}
\hline Type of industry & Sample (\%) \\
\hline Halal grains & $102(34.5)$ \\
\hline Halal food crops & $91(31.3)$ \\
\hline Cordial and juice & $36(12.2)$ \\
\hline Halal marine & $28(9.5)$ \\
\hline Halal meat & $21(7.0)$ \\
\hline Halal dairy & $17(5.5)$ \\
\hline Total & $295(100)$ \\
\hline
\end{tabular}

Table 2: The efficiency of halal grains industry

\begin{tabular}{|c|c|c|c|c|c|c|}
\hline Input & Range & Efficient (\%) & $\begin{array}{c}\text { Less Efficient } \\
(\%)\end{array}$ & $\begin{array}{c}\text { Inefficient } \\
(\%)\end{array}$ & $\begin{array}{l}\text { Total } \\
(\%)\end{array}$ & Total $(\%)$ \\
\hline \multirow{3}{*}{$\begin{array}{l}\text { Local raw input } \\
(\%)\end{array}$} & $<50$ & 1.9 & 2.9 & 17.6 & 22.5 & \multirow{3}{*}{100} \\
\hline & $50-<100$ & 1.9 & 0.0 & 35.3 & 37.2 & \\
\hline & 100 & 0.0 & 0.9 & 39.2 & 40.1 & \\
\hline \multirow{3}{*}{$\begin{array}{l}\text { Labour (number } \\
\text { of people) }\end{array}$} & $<20$ & 1.9 & 1.9 & 41.2 & 45.1 & \multirow{3}{*}{100} \\
\hline & $20-100$ & 0.9 & 1.9 & 49.0 & 51.9 & \\
\hline & $>100$ & 0.9 & 0.0 & 1.9 & 2.9 & \\
\hline \multirow{3}{*}{$\begin{array}{l}\text { Capital (RM } \\
\text { million) }\end{array}$} & $<0.5$ & 0.0 & 0.0 & 3.9 & 3.9 & \multirow{3}{*}{100} \\
\hline & $0.5-2.5$ & 2.9 & 2.9 & 77.5 & 83.3 & \\
\hline & $>2.5$ & 0.9 & 0.9 & 10.8 & 12.8 & \\
\hline \multirow{2}{*}{\multicolumn{2}{|c|}{ Average value TFP }} & (1.0000) & $(0.7382)$ & $(0.0506)$ & $(0.1148)$ & \\
\hline & & 3.9 & 3.9 & 92.1 & 100 & \\
\hline
\end{tabular}

* Numbers in () are in unit.

the same weight, and has a relative efficiency measurement that does not exceed the unity. By using this way, the optimum performance of a firm can be determined.

\section{Results \& Discussion}

Three input were used in the DEA analysis which were local raw input, the number of labours, and the amount of capital. While, the output were the gross sales of the firm.
The total number of firm participated in this study was 295 firms. Majority of the firms participated were from halal grains industry (102 firm), followed by halal food crops (91 firm), cordial and juice (36 firm), halal marine product (28 firm), halal meat (21 firm), and halal dairy (17 firm).

\section{Efficiency of Halal Grains Industry}

Based on the survey conducted on 102 samples halal grains firms, only $40.1 \%$ of the firms have been using $100 \%$ local raw inputs in the halal grains industry. In other words, almost $60 \%$ of the firms have been relying on imported 
raw inputs. These findings support the report provided by SMECorp (2010) concerning that Malaysia's halal grain industry depends on imported raw inputs. Idris et al. (2007) also found that almost $80 \%$ of the halal grains industry depend on imported raw inputs. One of the major concerns is that none of the firms that have been using $100 \%$ local raw inputs is considered efficient.

Majority of the firms have 20 to 100 labour $(52.9 \%)$ and followed by the firms that have less than 20 labour (45.1\%), and only $2.9 \%$ of firms have more than 100 labour. Majority of the firms in the industry have a capital ranging from RM 500,000 to RM 2.5 million (83.3\%). However, based on the results, the percentage of firms that are efficient was as low as $2.9 \%$ compared to the percentage of inefficient firms $(77.5 \%)$. Thus, having a larger capital does not yield higher efficiency value, it lies on how the capitals are being used and managed.

Overall, majority of the firms in halal grains industry were found to be inefficient (92.1\%) with 0.05 of average value TFP. While $3.9 \%$ of the firms were found to be less efficient (average value TFP $=0.74$ ) and another $3.9 \%$ (average value TFP $=1.00$ ) of the firms were considered efficient in halal grains industry. The average halal grains industry TFP was
0.11 , hence showed low efficiency in halal grains industry.

\section{Efficiency of Halal Food Crops Industry}

Based on the survey conducted on 91 halal crops food firms, $40.7 \%$ of the firms have been using $100 \%$ local raw inputs, $47.3 \%$ acquired at least $50 \%$ local raw inputs, and $12.1 \%$ of the firms have been using less than $50 \%$ of local raw inputs. The use of local raw inputs are believed to provide positive influence on the efficiency and cost-benefits of the firms to compete in the market as the delivery time and freight cost could be minimized compared to using imported raw inputs. Furthermore, the after service operations such as returning damaged goods could be performed in a timely manner. Nevertheless, only $7.7 \%$ of the firms was considered efficient in using local raw input. Majority of the firms $(52.8 \%)$ have less than 50 labour, $41.8 \%$ have 20 to 50 labour, and only $5.5 \%$ of the firms have more than 100 labour. None of the firms that have more than 100 labour was considered efficient.

From capital perspective, majority of the firms in the halal crops industry have a capital between RM 0.5 million to RM 2.5 million (43.9\%), while $41.8 \%$ have a capital less than RM 0.5 million (41.8\%), and $14.3 \%$ have a capital more

Table 3: The efficiency of halal food crops industry

\begin{tabular}{|c|c|c|c|c|c|c|}
\hline Input & Range & Efficient (\%) & Less Efficient (\%) & Inefficient (\%) & Total (\%) & Total (\%) \\
\hline \multirow{3}{*}{ Local raw input (\%) } & $<50$ & 3.3 & 1.1 & 7.7 & 12.1 & \multirow{3}{*}{100} \\
\hline & $50-<100$ & 1.1 & 10.1 & 35.2 & 47.3 & \\
\hline & 100 & 3.3 & 4.4 & 32.9 & 40.7 & \\
\hline \multirow{3}{*}{ Labour (number of people) } & $<20$ & 4.4 & 5.5 & 42.9 & 52.8 & \multirow{3}{*}{100} \\
\hline & $20-100$ & 3.3 & 8.8 & 29.7 & 41.8 & \\
\hline & $>100$ & 0.0 & 2.2 & 3.3 & 5.5 & \\
\hline \multirow{3}{*}{ Capital (RM million) } & $<0.5$ & 1.1 & 3.3 & 39.6 & 43.9 & \multirow{3}{*}{100} \\
\hline & $0.5-2.5$ & 6.6 & 10.1 & 24.2 & 41.8 & \\
\hline & $>2.5$ & 0.0 & 2.2 & 12.1 & 14.3 & \\
\hline \multirow{2}{*}{\multicolumn{2}{|c|}{ Average TFP value }} & $(1.0000)$ & $(0.5994)$ & $(0.0915)$ & $(0.2451)$ & \\
\hline & & 7.7 & 16.5 & 75.8 & 100 & \\
\hline
\end{tabular}

* Numbers in () are in unit. 
than RM 2.5 million. None of the firms that have a capital more than RM 2.5 million were efficient but only a small percentage of efficient firms have a capital less than RM 0.5 million (1.1\%), and 6.6\% have a capital between RM 0.5 million and RM 2.5 million. Thus, the efficiency of halal food crops industry does not necessarily depend on the amount of capital.

The total average TFP value obtained for halal food crops industry $(0.2451)$ clearly indicated low-level efficiency. Only $7.7 \%$ of the efficient firms scored TFP value 1.0 and majority of the firms have been operating with less than 100 labour with a capital less than RM 2.5 million.

\section{Efficiency of Halal Marine Products Industry}

Table 4: The efficiency of halal marine products industry

\begin{tabular}{|c|c|c|c|c|c|c|}
\hline Input & Range & Efficient (\%) & $\begin{array}{c}\text { Less Efficient } \\
(\%)\end{array}$ & Inefficient (\%) & Total (\%) & Total (\%) \\
\hline \multirow{3}{*}{ Local raw input (\%) } & $<50$ & 7.1 & 0.0 & 10.7 & 17.9 & \multirow{3}{*}{100} \\
\hline & $50-<100$ & 7.1 & 0.0 & 39.3 & 46.4 & \\
\hline & 100 & 0.0 & 7.1 & 28.8 & 35.7 & \\
\hline \multirow{3}{*}{ Labour (number people) } & $<20$ & 7.1 & 3.6 & 25.0 & 35.7 & \multirow{3}{*}{100} \\
\hline & $20-100$ & 7.1 & 3.6 & 50.0 & 60.7 & \\
\hline & $>100$ & 0.0 & 0.0 & 3.6 & 3.6 & \\
\hline \multirow{3}{*}{ Capital (RM million) } & $<0.5$ & 3.6 & 7.1 & 21.4 & 32.1 & \multirow{3}{*}{100} \\
\hline & $0.5-2.5$ & 7.1 & 0.0 & 28.6 & 35.7 & \\
\hline & $>2.5$ & 3.6 & 0.0 & 28.6 & 32.1 & \\
\hline \multirow{2}{*}{\multicolumn{2}{|c|}{ Average TFP value }} & $(1.0000)$ & $(0.7274)$ & $(0.11416)$ & $(0.2845)$ & \\
\hline & & 14.2 & 7.2 & 78.7 & 100 & \\
\hline
\end{tabular}

Based on the survey conducted on 28 halal marine firms, majority of the firms (46.4\%) have been using 50 to less than $100 \%$ local raw input, while $35.7 \%$ of the firms have been using 100\% local raw input, (and 17.9\% have been using less than 50\% local raw input. None of the firms that use $100 \%$ local raw input was considered efficient. In terms of labour, majority of the firms $(60.7 \%)$ employs between 20 and 100 labour, $35.7 \%$ have less than 20 labour, and $3.6 \%$ have more than 100 labour. From capital perspective, majority of the firms (35.7\%) in this industry have a capital in the range of RM 0.5 million to RM 2.5 million, $32.1 \%$ of the firms have capital less than RM 0.5 million, and another $32.1 \%$ have more than RM 2.5 million

Overall, $14.2 \%$ of the firms were considered efficient $(\mathrm{TFP}=1.00), 7.2 \%$ were considered less efficient $(\mathrm{TFP}=0.72739)$, and $78.7 \%$ were considered inefficient $(\mathrm{TFP}=0.11)$. The total average TFP value obtained ( 0.28$)$ showed that halal marine industry is not efficient.

\section{Efficiency of Halal Meat Industry}

Based on the survey conducted on 21 halal meat firms, $28.6 \%$ of the firms have been using $100 \%$ local raw input are, while $38.1 \%$ have been using 50 to $100 \%$ local raw input, and $33.3 \%$ have been using less than $50 \%$ local raw input. There were only $9.5 \%$ efficient firms, and they acquired raw inputs from local providers.
Nevertheless, $19 \%$ inefficient firms have been using 100\% local raw input.

In terms of labour, majority of the firms in halal meat industry have 20 to 100 labour representing $47.6 \%$ of the total labour force. $33.3 \%$ have less than 20 labour and $19.0 \%$ have more than 100 labour. In terms of capital, majority of the firms $(47.6 \%)$ in this industry have a capital between RM 0.5 million and RM 2.5 million. 38.1\% have a capital more than RM 2.5 million and $14.3 \%$ have capital less than RM 0.5 million.

The percentage of efficient firms was $9.5 \%$ (TFP $=1.00)$, the percentage of less efficient firms 
was $28.6 \%(\mathrm{TFP}=0.75)$ and the percentage of inefficient firms was $61.9 \%(\mathrm{TFP}=0.21)$. The average TFP of halal grains industry was 0.44 , hence showed medium efficiency but the level of efficiency is still low.

Table 5: The efficiency of halal meat industry

\begin{tabular}{|c|c|c|c|c|c|c|}
\hline Input & Range & Efficient (\%) & $\begin{array}{c}\text { Less Efficient } \\
(\%)\end{array}$ & Inefficient (\%) & Total (\%) & Total (\%) \\
\hline \multirow{3}{*}{ Local raw input (\%) } & $<50$ & 0.0 & 14.3 & 19.0 & 33.3 & \multirow{3}{*}{100} \\
\hline & $50-<100$ & 0.0 & 9.5 & 28.6 & 38.1 & \\
\hline & 100 & 9.5 & 0.0 & 19.0 & 28.6 & \\
\hline \multirow{3}{*}{ Labour (number people) } & $<20$ & 4.8 & 14.3 & 14.3 & 33.3 & \multirow{3}{*}{100} \\
\hline & $20-100$ & 0.0 & 4.8 & 42.9 & 47.6 & \\
\hline & $>100$ & 4.8 & 9.5 & 4.8 & 19.0 & \\
\hline \multirow{3}{*}{ Capital (RM million) } & $<0.5$ & 0.0 & 14.8 & 9.5 & 14.3 & \multirow{3}{*}{100} \\
\hline & $0.5-2.5$ & 9.5 & 14.3 & 23.8 & 47.6 & \\
\hline & $>2.5$ & 0.0 & 9.5 & 28.6 & 38.1 & \\
\hline \multirow{2}{*}{\multicolumn{2}{|c|}{ Average TFP value }} & $(1.0000)$ & $(0.7500)$ & $(0.2057)$ & $(0.4368)$ & \\
\hline & & 9.5 & 28.6 & 61.9 & 100 & \\
\hline
\end{tabular}

${ }^{\star}$ Numbers in () are in unit.

\section{Efficiency of Halal Dairy Industry}

Based on the survey conducted on 17 firms in halal dairy industry, majority of the firms (41.2\%) have been using 50 to $100 \%$ local raw input, 35.3\% have been using less than 50\% local raw input, and $23.6 \%$ have been using $100 \%$ local raw input.

Table 6: The efficiency of halal dairy industry

\begin{tabular}{|c|c|c|c|c|c|c|}
\hline Input & Range & Efficient (\%) & $\begin{array}{c}\text { Less Efficient } \\
(\%)\end{array}$ & Inefficient (\%) & Total (\%) & Total (\%) \\
\hline \multirow{3}{*}{ Local raw input (\%) } & $<50$ & 1.7 & 5.9 & 17.6 & 35.3 & \multirow{3}{*}{100} \\
\hline & $50-100$ & 0.0 & 5.9 & 35.3 & 41.2 & \\
\hline & 100 & 5.9 & 0.0 & 17.6 & 23.6 & \\
\hline \multirow{3}{*}{ Labour (number of people) } & $<20$ & 5.9 & 0.0 & 17.6 & 23.6 & \multirow{3}{*}{100} \\
\hline & $20-100$ & 17.6 & 1.7 & 29.4 & 58.8 & \\
\hline & $>100$ & 0.0 & 0.0 & 17.6 & 17.6 & \\
\hline \multirow{3}{*}{ Capital (RM million) } & $<0.5$ & 1.7 & 0.0 & 27.6 & 29.4 & \multirow{3}{*}{100} \\
\hline & $0.5-2.5$ & 0.0 & 1.7 & 21.7 & 23.5 & \\
\hline & $>2.5$ & 1.7 & 0.0 & 35.3 & 47.1 & \\
\hline \multirow{2}{*}{\multicolumn{2}{|c|}{ Average TFP value }} & $(1.0000)$ & $(0.8169)$ & $(0.1401)$ & $(0.4221)$ & \\
\hline & & 23.5 & 11.8 & 64.7 & 100 & \\
\hline
\end{tabular}

${ }^{*}$ Numbers in () are in unit.
In terms of capital, $47.1 \%$ of the firms have a high capital of more than RM 2.5 million. Nevertheless, the percentage of efficient firm within this percentile was as low as $1.7 \%$. In contrast, the percentage of inefficient firms obtained was as high as $35.3 \%$.

The percentage of efficient firms in the halal dairy industry was $23.5 \%(\mathrm{TFP}=1.00)$. In contrast, the
In terms of labour resources, most of the firms (58.8\%) have between 20 to 100 labour, 23.6\% have less than 20 labour, and $17.6 \%$ have more than 100 labour. All firms that employ more than 100 labour were found to be inefficient. Majority of the efficient firms are employing 20 to 100 workers. 
TFP value for less efficient firms was as high as $0.82(11.8 \%)$ and for inefficient firms was 0.14 $(64.7 \%)$. However, the total average of TFP value for dairy industry was 0.422 , indicating its ability to compete in terms of efficiency is still lower than 0.5 .

\section{Efficiency of Halal Cordial and Juice Industry}

Based on the survey conducted on 36 firms in halal cordial and juice industry, majority of the firms $(58.3 \%)$ have been using 50 to $100 \%$ local raw input, $22.2 \%$ have been using less than $50 \%$ local raw input, and $19.9 \%$ have been using $100 \%$ local raw input. All firms that have been using $100 \%$ local raw input were found to be inefficient (19.9\%).

All firms which have 20 to 100 labour showed
The total average TFP value of halal cordial and juice industry was as low as 0.29 , which is far from the optimum efficiency value of 1.0. In addition, the percentage of firms considered to be efficient was $5.6 \%$. Basically, this industry is efficient in managing their labour resources despite acquiring large amount imported raw inputs.

\section{Conclusion}

The majority of halal food industries are not efficient due to the score of DEA efficiency obtained which was less than 1.0. The percentage of efficient firms in each industry was quite small (dairy products $(23.5 \%)$, halal marine products (14.2\%), halal meat (9.5\%), halal food crops products $(7.7 \%)$, cordial and juice $(5.6 \%)$, and halal grains $(3.9 \%))$.

Table 7: The efficiency of halal cordial and juice industry

\begin{tabular}{|c|c|c|c|c|c|c|}
\hline Input & Range & Efficient (\%) & $\begin{array}{c}\text { Less Efficient } \\
(\%)\end{array}$ & Inefficient $(\%)$ & Total $(\%)$ & Total $(\%)$ \\
\hline \multirow{3}{*}{ Local raw input $(\%)$} & $<50$ & 2.8 & 0.0 & 19.4 & 22.2 & \multirow{3}{*}{100} \\
\hline & $50-<100$ & 2.8 & 0.0 & 55.6 & 58.3 & \\
\hline & 100 & 0.0 & 0.0 & 19.9 & 19.9 & \\
\hline \multirow{3}{*}{ Labour (number of people) } & $<20$ & 2.8 & 0.0 & 44.4 & 47.2 & \multirow{3}{*}{100} \\
\hline & $20-100$ & 2.8 & 0.0 & 47.2 & 50.0 & \\
\hline & $>100$ & 0.0 & 0.0 & 2.8 & 2.8 & \\
\hline \multirow{3}{*}{ Capital (RM million) } & $<0.5$ & 0.0 & 0.0 & 25.0 & 25.0 & \multirow{3}{*}{100} \\
\hline & $0.5-2.5$ & 5.6 & 0.0 & 58.3 & 63.9 & \\
\hline & $>2.5$ & 0.0 & 0.0 & 11.1 & 11.1 & \\
\hline \multirow{2}{*}{\multicolumn{2}{|c|}{ Average TFP value }} & $(1.0000)$ & $(0.0)$ & $(0.0250)$ & $(0.2918)$ & \\
\hline & & 5.6 & 0.0 & 94.5 & 100 & \\
\hline
\end{tabular}

* Numbers in () are in unit.

the highest percentage $(50 \%)$ in the labour resources section. Nevertheless, within this percentage, only one firm was found to be efficient $(2.8 \%)$.

Moreover, only one firm has more than 100 labour $(2.8 \%)$, though operating inefficiently. The highest percentage of efficiency within the efficient firms was 5.6\% which lies in the capital ranging from RM 0.5 million to RM 2.5 million. The rest of the firms $(94.0 \%)$ were grouped as inefficient.
The firms that possessed higher average TFP were halal meat (0.44) and halal dairy (0.42). While the other TFP values for halal cordial and juice, halal marine, halal food crops, and halal grains were $0.29,0.28,0.25$, and 0.11 respectively. Even though Malaysia is one of the main exporter of grains in the world, the efficiency of halal food grains industry is the lowest compared to others.

The quality of raw inputs and labour skills should also be improved to increase the efficiency of the 
industry. Since most of the raw inputs acquired locally do not meet the required specifications (SMECorp, 2010), this hampers the efficiency of the operations in the industry. The high demand for quality industrial end products also show that consumers have paid great attention to the quality and safety of consumable products but the efficiency of labour in the halal food industries is low.

Therefore, the government should help the industry to increase their efficiency by providing assistance to the firms involved to realise the country's interest in becoming one of the major hubs for halal food distribution in the future. Each industry is also required to cultivate their labour skills further in order to improve its productions, efficiency, and productivity.

\section{References}

Brown, J. D., \& Earle, J. S. (2000). Competition and firm performance: Lessons from Russia. Working paper of Stockholm Institute of Transition Economics. Stockholm School of Economics, Stockholm, 1-33.

Charnes, A., Cooper, W.W. \& Rhodes, E. (1978). Measuring the efficiency of decision making units. European Journal of Operational Research, 2, 429-444.

Charnes, A., \& Cooper, W. W. (1984). Preface to topics in data envelopment analysis. Annals of Operation Research, 2, 59-94.

Cook, W. D., \& Zhu, J. (2006). Modeling performance measurement: applications and implementation issues in DEA (Vol. 566). Springer Science \& Business Media.

Cooper, W. W., \& Lovell, C. A. K. (2000). New approach to measure of efficiency in DEA: An introduction. Journal of Productivity Analysis, 13(2):81-91.

Farrell, M. J. (1957). The measurement of productive efficiency. Journal of the Royal
Statistical Society. Series A(General), 253-290.

Halal Development Corporation (HDC). (2010). Halal Industry. www. hdc.com.my.

Idris, N. A, Shahdan, F., Bakar, N. A., Dan, A. R., \& Noor, M. A. M (2007). Malaysia ke arah hab makanan halal dunia. Dewan Bahasa dan Pustaka (DBP), Kuala Lumpur.

Ismail, M. M., \& Radam, A. (2004). Competitiveness of the Malaysian food processing industry. Universiti Putra Malaysia Press.

Nickell, S. J. (1996). Competition and corporate performance. Journal of political economy, 104, 724-746.

Noor, Z. M., \& Ismail, R. (2007). Analisis kecekapan teknik dalam industri skel kecil dan sederhana di Malaysia. International Journal of Management Studies, 14 (1): 199-217.

Norman, M., \& Stoker, B. (1991). Data Envelopment Analysis. John Wiley \& Sons, England

Raziah, M. L. (2003). Penilaian kecekapan firma pemprosesan produk makanan berasaskan ikan di Malaysia, 1996-1998. Journal of Tropical Agriculture and Food Science, 31 (2): 273.

SMECORP. (2010). Laporan tahunan EKS. http://www.smidec.gov.my/access.

Sungkar, I. (2004). Beyond our borders: Export opportunities in the Middle East, Japan and Hong Kong. In MEATEC Forum, Livestock Asia Exhibition, Serdang, Malaysia.

Tavares, G. (2003). A bibliography of data envelopment analysis (1978-2001). Rutcor Research Report. New Jersey, USA: Rutgers Center for Operations Research, Rutgers University.

Webster, R., Kennedy, S., \& Johnson, L. 
GJAT | JUNE 2016 | VOL 6 ISSUE 1 | 46

ISSN : 2232-0474 | E-ISSN : 2232-0482

www.gjat.my

(1998). Comparing technique for measuring the efficiency and the productivity of Australian private hospitals. Working Papers in Econometrics and Applied Statistics No 98/3. Australian Bureau of Statistics. 1-60. 